\title{
FEMINIST EPISTEMOLOGY AND THE SEARCH FOR LIBERATING KNOWLEDGE
}

\author{
Rachmad Hidayat \\ Universitas Gadjah Mada \\ Email: rachmadhidayat@ugm.ac.id
}

\section{Abstrak}

Artikel ini mendiskusikan persoalan maskulinisme dalam pengetahuan dan aktivitas ilmiah serta menelusuri strategi epistemologis alternatif dalam rangka mencapai model pengetahuan yang membebaskan dan tanpa dominasi. Dalam perspektif feminisme, isu mendasar dalam epistemologi dan filsafat ilmu mainstream adalah konsep pengetahuan dan praktek ilmiah yang diterima mengingkari pengaruh dimensi sosial dan politik terhadap aktivitas mengetahui beserta hasil-hasilnya. Analisis feminis melihat bahwa dominasi laki-laki dan maskulinisme yang mencirikan struktur dan norma sosial yang mapan telah mereproduksi karakter dominatif tersebut ke dalam praktik dan standard pengetahuan yang objektif. Artikel ini bermaksud untuk menjawab dua pertanyaan. Pertama, bagaimana maskulinisme sebagai norma sosial dan politik yang dominan mempengaruhi produksi pengetahuan? Kedua, strategi epistemologi apa yang dapat ditempuh untuk menghasilkan pengetahuan yang membebaskan dan tidak bersifat mendominasi? Teori pengetahuan feminis berlandaskan pada keyakinan bahwa penyelidikan rasional adalah praktik sosial di mana gender sebagai norma dan referensi kultural dan politik memberikan pengaruh mendalam terhadap proses mengetahui dan hasilhasilnya. Teori pengetahuan yang membebaskan mensyaratkan pengakuan terhadap berbagai metode dan model pengetahuan yang sesuai dengan situasi spesifik subjek yang mengetahui. Dengan pemahaman epistemologi tersebut, pemikir feminis memformulasikan berbagai strategi mengetahui untuk mereduksi muatan maskulinisme dalam praktik pengetahuan dan ilmu yang mapan.

Kata-kata kunci: epistemologi feminis, produksi pengetahuan, gender, maskulinisme

\section{Abstract}

This paper discusses problems in dealing with masculinized knowledge and 
scientific enterprises, and seeks alternative epistemological strategies in achieving liberating and un-dominated knowledge production. A general problem with "mainstream" epistemology and philosophy of science from feminist perspectives is that the well accepted concept of knowledge and scientific practices derived from it deny the impacts of social and political dimension toward knowing activities and their results. Feminists observed that men and their masculinities have been reproducing their social and political domination into the practices and standard of objective knowledge. The paper takes on two questions. First, how masculinity as dominant social and political norm has influence the production of knowledge? Second, what epistemological strategies would allow the production of less dominating and liberating knowledge? Feminist theories of knowledge built on the belief that rational inquiry is social practice through which gender as cultural and political norms and reference give deep impacts toward knowing process and it results. A theory of liberating knowledge requires acknowledgement and acceptance of multiple methods and models of knowledge in accordance to specific situation of the knowing subjects. Through such epistemological understanding feminist theorists formulated epistemological strategies to reduce masculinity in the rational inquiries and well accepted science.

Keywords: feminist epistemology, knowledge production, gender, masculinity

\section{INTRODUCTION}

This paper discusses feminist theories in dealing with masculinized knowledge and in exploring alternative epistemological strategies to produce liberating and un-dominated knowledge. The mainstream epistemology and the philosophy of science derived from it have been operating under the assumption that the social position and gendered bodies of subject of knowledge have no relevance on epistemological endeavor (Nelson 1995). Many theoretical streams in epistemology and the philosophy of science show very little interest in bringing claims on knowledge, epistemological framework, or epistemology itself into historical consideration. There has been long existed among the most influential epistemological traditions the premise that a general theory of knowledge is possible.

It is exactly against this premise that feminist theorists have launched their critics toward mainstream epistemological thinking 
and further developed their own theories of knowledge. In contrast to the mainstream epistemology, the very premise of feminist epistemology asserts that rational inquiry is a social endeavor (Longino 1990; Nelson 1993). Feminist theorists heavily stress on the significance of the social, cultural and political context on the activity of knowing. In this context, gender deeply affects the knowledge production by the knowing subject. Linda Alcoff and Elizabeth Potter (1993), for example, suggest that the social status and "the sexed body of the knower" have impact on the production of knowledge and further to the notion of "universality" of knowledge being sought and claimed by mainstream epistemological enterprise (p. 13). This "universal" notion of knowledge presumes that subject of knowledge has no gender and represents anyone capable of undertaking rational activities. However, as Code argues, such epistemological model implicitly presupposes a male knower (Code 1991). That is to argue that the contemporary epistemological core model is the embodiment of men's way knowing and men's way thinking.

As a tradition of epistemology, feminist epistemological inquiries centre on a range of influences of gender as social norms, discourses and social structure on the production of knowledge. At the same time, feminist theorists analyse how the production of knowledge give impact to social, political and cultural standing of women and other marginalised groups. There is no, or may never, single representation of feminist epistemology (Alcoff and Potter 1993). Feminist epistemology comprises of diverse (and not always compatible each other), dynamic and far from complete theoretical projects (Nelson 1995).

While demonstrating very strong critical orientation, feminist epistemology seriously takes constructive efforts further. Critical characteristic uncovers various forms of masculine tendencies at the center of philosophical enterprises on topics such as objectivity, reason, subjectivity, knowledge, and rationality. Constructive element of feminist epistemology includes engraving out rooms for feminist intellectual inquiries, exploring and constructing models for liberating or non-dominating theoretical agendas. In this constructive epistemology field, feminist standpoint theory, feminist empiricism, 
and, increasingly, feminist pragmatism are the most profound contributors to the tradition (See Lloyd 1984, Code 1991, 1995, Harding 1986, 1991, Rooney 1994, 1995, Anderson 1995, Solomon 1995, also Alcoff and Potter 1993, Lennon and Whitford 1994).

In response to the mainstream theories of knowledge, feminist epistemological project drives toward two main objectives. First, it attempts to reveal various forms and levels of sexism and masculine bias lying under theoretical inquiries. Second, feminist epistemology seeks to provide theoretical grounds which incorporate a commitment to liberation of women and other socially and politically oppressed groups of people (Longino 1993a). With regards to these aims, this article addresses two central questions within feminist epistemological inquiries. First, how masculinity take forms in the production of knowledge? Second, what epistemological strategies would allow the production of less dominating and liberating knowledge?

\section{DISCUSSION}

\section{Knowledge Production and Masculine Domination}

One of the most well accepted notions of knowledge in the Western epistemological tradition is presented in the formula "S knows that $\mathrm{P}$ ". This formula presumes object of knowledge to be independent and readily observable to the mind of the knower. At the same time it requires subject of knowledge to be impersonal, emotionally detached, oriented to things rather than persons, and oriented to an "objective" form of its knowledge object. The impersonality of subject of knowledge presumes that the knowing subject has no sex. This formula shapes the widely adopted conceptions of objectivity that asserts the possibility of objective knowledge as the "view from nowhere" (Daston and Gallison 2007). This conception implies that all other points of view are invalid or biased.

That requirement of subject of knowledge to be impersonal, emotionally detached, and oriented to things rather than persons and independent to the object sits at the center of feminist critic on epistemology. Feminists such as Sandra Harding (1989) and Susan 
Bordo (1995) had revealed that such features of subject are stereotypically attributed to men and represent masculine gendered symbols. These features are in conjunction with the dominant gendered representation of masculinity and femininity as opposed each other and mutually exclusive. What is more dangerous, such set of features, in feminist perspective, implicitly abandon the epistemic capabilities and authority of women and other marginalized groups. It is a shared notion within feminist theories that objectivity has history and produced within certain historical contexts (Daston and Gallison 2007). Gender is a crucial dimension shaping that historical context.

A crucial aspect of feminist critical tradition examines how mainstream epistemological concepts give impacts to political, social and cultural marginalization of women and other subordinate groups. Feminist critiques focus on how the notion of impersonal, emotionally detached and independent subject has created masculine domination and epistemic exclusion toward women and other marginalized groups. Feminist critiques identify at least two main implications of this theory of knowledge that produce masculine domination in epistemological enterprises, namely epistemic injustice and epistemic ignorance.

Epistemic injustice takes place when mainstream theory of knowledge allows the dominant groups to monopolize epistemic authority for themselves. At the same time they disregard the epistemic capacity of subordinate groups by creating stereotypes that stigmatize subordinate groups as incompetent or untruthful with regard to the production of knowledge. They promote cultural markers that symbolize epistemic authority based on characteristics associated with their group such as sense on honor, moral credibility or political importance among elites group of men (Addelson 1983; Shapin 1994). Political, social and cultural structures allow the dominant group to secure access to these markers, namely access to institutions of knowledge such as higher education is made limited against subordinate groups. This power oriented tendencies undermines the ability of subordinate groups to contribute to epistemological enterprise, whereby committing epistemic injustice 
against these groups. The dominant group of epistemological narrative particularly referred to White, middle-upper class, males.

A frequent case that can be categorized as a form of epistemic injustice is what Fricker (2007) calls "testimonial injustice." It refers to a scenario when dominant epistemic atmosphere lead society, partly or in majority, to disregard credibility of marginalized individuals or groups to voice out their narrative because of prejudice against these groups or their low social standing. Official denials of testimonies by women or children victims of sexual abuse committed by respected or powerful public figures (political leaders, religious leaders, adored celebrities, university professors) are frequent cases of testimonial injustice. Dotson (2011) explains that testimonial injustice operates in two mechanisms, namely silencing and smothering. Testimony silencing operates when the narrator's testimony being denied or disregarded particularly on the basis of prejudice against the narrator's identity or credibility. Testimony smothering occurs when the a member subordinate groups silences her own voices or keeps her story out of recognition due to fear of being misunderstood, denied, or causing more harmful prejudice their own groups and her identity. For example, women victims of exploitation (sexually, economically, religiously or politically) are often reluctant to voice out or testify against powerful and respected figures or institutions because their testimony more likely to reinforce cultural prejudices against women for being weak, sexually provoking, dishonest, morally weak, emotional or intellectually incompetent.

Hookway (2010) argues that testimonial injustice politically and socially excludes subordinate groups from participation in the production of public knowledge in general. Such epistemic exclusion may take forms in the exclusion of subordinate groups to engage in the activities of knowledge production including asking questions, proposing different perspectives or points of view, raising objections, and suggesting alternative arguments. When the dominant epistemic community does not take such contributions into serious consideration out of prejudice against the speaker's social and cultural identity, epistemic injustice is taking place against the speaker both as a subject of knowledge and as a member of epistemic community. 
There is a close link between epistemic injustices and epistemologies of ignorance. Epistemic injustice involves systematic ignorance that affects the social and political standing of subordinated groups as subject of knowledge. Epistemic ignorance may take forms in deliberately forgetting or taking no attention to certain crucial matters in the knowledge production. The authoritative knowledge institutions, for example, possess the capacity to develop knowledge meaningful to subordinated groups but chose to ignore the importance of such knowledge (Tuana 2006). The negligence of women's philosophers in the canonic history of Western philosophy is a very clear example of such ignorance. Epistemic ignorance also closes the possibilities of or represses academic enterprises that uncover the prevalent injustices system and practices.

According to Margonis (2007) epistemic ignorance could have further implications in weakening the capacities of subordinate groups to disseminate their knowledge to other groups, whereby diminishing their epistemic impact. In most cases, dominant groups would avoid the production of knowledge that lead to the truth of their own injustices system and practices (Margonis 2007). They could further establish hermeneutical ignorance that hinders their consideration and intellectual sense from the voices of the marginalized groups.

The discussion on epistemic domination above reinforces feminist points of view that epistemological inquiries are socially value-laden enterprises. What is more important, these value-laden rational endeavors have impacts on subordinating structure in the society. An aspect that feminist theorists employ to explain the social dimension of academic inquiry is the pragmatic component of scientific practice (Anderson 1995b).

Such pragmatic component precisely lays in very first step of research practice that is the research question. Every academic inquiry starts with questions). As Anderson (1995) observes, research questions may not be solely urged by rational motivation. A range of more practical interests in understanding particular phenomenon or in understanding problematic situations can also in fact lead to research questions. In such a common scenario, a scientific inquiry 
bears practical purposes too. The outcome of that inquiry then is directed by these rational cum-pragmatic interests. The pragmatic component of scientific inquiry suggests new aspect of judgment of theories. A theory can not only be evaluated based on their adequate supporting evidence to assure their credibility, but further based on their cognitive accessibility to the situated knowing subject upon application (Anderson 1995).

Even those theorists who strongly believe in the valueneutrality of rational knowledge and science are aware that pragmatic interests contribute to the choice of objects of scientific inquiries. This means that pragmatic interests, including social, cultural and political ones, are epistemic resources that shape the knowledge production. Different pragmatic interests will generate different inquiries and seek to discover different aspects of the world (Anderson 1995). However, supporters of dominant notion of value-neutrality in academic inquiries assert that when the research activities in taking place using rational instruments the scientific discoveries are fully determined by the natural world. In contrast to this notion, feminist epistemologists argue that the practical interests produce deeper impacts into how the discoveries are achieved. Subject of knowledge, in fact, play a more active role in constituting the object of knowledge than merely using the rational instruments. Here, "constitution" of object means in term of representational and causal. In term of representational, the knowing subject constitute the object of knowledge by creating terms or concepts to represent it, and by defining the context through which the representation is working. According to Helen Longino (1990), if knowing is comparable to seeing, every act of seeing is a form of "seeing as" and different interests will lead to see the "same" things differently. This is an avoidable implication if subject of knowledge is understood to be situated in certain context. This is further implication when subject of knowledge, or their identities, are considered to be socially constructed.

Feminist philosophers of science strongly emphasize how social, cultural and political values bring a range of influence in scientific activities and practices (Wylie and Nelson 2007). They examine how certain values are embodied in particular scientific 
practices and critically analyze whether these values hinder the discoveries of particular un-desirable facts, induce dogmatic thinking among subjects of knowledge, or isolate their findings from critical scrutiny, or whether these values open possibility for new discoveries (Anderson 2004). Privilege entitled to dominant groups and prejudices against marginalized groups are common contributors of such social values which provide reference for rational inquiries.

Anderson (1995) suggests that feminist theory on the social construction of rational inquiry brings two implications. First, the knowledge resulted from practices of inquiry may leave the traces of the social circumstances of the inquirers. It is fundamental to state that gender is crucial element of that circumstance that affects theoretical inquiry. Second, as feminist critiques reject certain ways through which gender brings the dominating characters the dominant groups into products of inquiry, demanding subjects of inquiry to be somehow detached from their gender or gender-related values is not the solution to address that domination (Anderson 1995).

\section{Feminist Theories of Objectivity}

The feminist critiques of epistemology identified masculine and class biases in the concept of objectivity which affect rational inquiries. They further took various attempts to develop feminist theories of objectivity. In doing so, feminist epistemologists and philosophers of science passed up debate on the ontological field, namely evaluating subject/object dichotomy, which define objectivity in the form of an a priori concept about what considered to be really exists. They opted to let the debate of what kinds of reality exist open.

Feminist theories of knowledge generally shared a clear intention to open room for plurality in ways of knowing. Epistemic communities have different interests, approach different aspects of the same world, and from that they build a range of theories to address particular epistemic and pragmatic issues. While a theory of the empirical world can only be justified through its supporting evidences, such procedure remains open for emergence of multiple theories with every theory may proclaim its own adequacy. Along with this acceptance of pluralistic models and method of knowing, 
most feminists epistemologist do not see the necessity of unifying these different models or theories, considering that they contain truths, into a single grand model of knowing which apply a single language or a single set of theoretical terms (Longino 2001). Harding (1998) and followed by Longino (2001) suggest that as long as different epistemic communities could maintain the adequacy of their associated theories in accordance to recognized standards, and open to criticism, their model of knowledge may each judged as objective. This is regardless different contents their theories may contain. However, Intemann (2011) challenges the risk of unlimited theoretical pluralism in democratic spirit which is supported by Longino (1990) and Solomon (2001). She contends that if sexism and racism exist in a scientific theories following sustained examination, then such cannot be funded or taken seriously.

Feminist epistemologists give strong emphasize on the situatedness or perspective-relativity of much knowledge that human reason can produce. However, they do not thereby embrace relativistic epistemology (Anderson 1995). To consider some knowledge claims or form of understanding as situated in certain perspectives is not to suggest that the perspective reveals true beliefs or acceptable understandings. Similarly, it does not mean that particular situated perspectives can only be judged according to their own terms. It is important to state that feminist epistemology does not reject the possibility or desirability to produce of objective knowledge. What feminist epistemologists do is proposing new perspectives about objectivity.

Feminist theories of knowledge have developed their conception of knowledge production centered to the notion of situatedness of knowledge. With this regard, three broad epistemological traditions have taken shape: feminist standpoint theory, feminist postmodern, and feminist empiricism (Harding 1990). Feminists standpoint theory believe that particular perspective departing from disadvantageous position, i.e. women and marginalized groups, inhabit epistemic privilege. However, postmodern feminists reject such claims of epistemic privilege, while give emphasize on the contingency and instability of the social 
identity of knowing subjects and their representations. Feminists empiricist explore framework to differentiate the situation in which situatedness of the knower creates bias and in which circumstances it provides a resource to advance knowledge. This notion expands a conception of objectivity as constituted by critical while cooperative relations among different situated knowers.

A number of feminist theorists stressed the epistemic benefit of involving emotional response to the object of knowledge for the constitution of knowledge. Emotions could serve as epistemic functions crucial for moral and political inquiry mediating inquirers to specifics features of the world he/she trying to know (Jaggar 1989, Little 1995, Anderson 2005). Generally in social science disciplines, emotional engagement with one's subjects of study is often required to understand and interpret sensitive issues or unique phenomenon. The fields of anthropology, sociology or human geography for examples, enquirers often need to build trust from their subjects and to attain a rapport with them to interpret their complex and unique world (Hrdy 1986).

It was Evelyn Fox Keller (1985a) who has developed an idea of objectivity as emotional engagement with object of knowledge in her concept of "dynamic objectivity." With dynamic objectivity, enquirers employ a mode of perception based on sense of love toward the objects. Keller argues that this way of knowing is more adequate compared to objectivity as detachment. This is precisely because this way does not involve a neurotic requirement to allay anxieties about maintaining the independence of the knowing subject by dominating the object of study, as stated in the mainstream epistemology doctrine. Longino (1993b) has objected to Keller's concept on with reason that while dynamic objectivity may involve a less neurotic mode of relation with the world, this does not show that as an epistemology concept it is better one. Keller's study of Barbara McClintock's ground breaking discovery of genetic transposition (1983), proposed an exemplary model of Keller's dynamic objectivity. McClintock's study demonstrated the epistemic advantage of sense of love toward the objects of study. 
Moving further from Keller's theory of knowledge, Sandra Harding (1993) argued that the objectivity of knowledge should be sought through reflexivity. Harding is a key figure in feminist standpoint theory. Notion of reflexivity asks subject of knowledge to posit themselves on the same circumstances or situation as the object of knowledge. When constituting their knowledge, enquirers must explicitly reveal their social positions, interests, background assumptions, biases, and other contingent. The same goes with their perspectival features that shape their inquiry questions, research methods, and interpretations which the enquirers apply during knowing process. With such reflexivity strategy, Harding admitted the partiality of any representations while not denying their possibility to claim truth (Harding 1993). The theory implies that representation can be true without achieving the whole truth about the object being represented. Reflexivity enhances objectivity by avoiding overlapping between one's own partial perspective and a comprehensive view, and by highlighting dependency of representation that could be questioned. Harding argued (1993) that inclusion of marginalized groups into rational inquiry will enhance reflexivity. This is because the marginalized groups are more likely to encounter with components of accepted representations shaped by unchallenged application of the perspectives of the dominant groups.

Harding (1993) advanced her theory of strong objectivity by further including democratic inclusion as key feature of objective inquiry in addition to principle of reflexivity. She formulated this notion as a reconfiguration of standpoint theory. The theory entitles the standpoints of marginalized groups a fundamental role in achieving objective knowledge. However, according to strong objectivity, such epistemic privilege does not apply to the standpoints of the oppressed when considered from their own terms. Rather, it prefers representation constituted by communities that include them over representations created by communities that exclude them.

However, feminist postmodernists' critique of standpoint theory suggests that there is no in fact a single overreaching women's group that legitimately represent women's standpoint which therefore warrant epistemic superiority (Harding 1998). Socially, politically and 
culturally women's situation and experience are vary and this give rise of the multiple standpoints of subaltern women's (namely black, Latina, lesbian, postcolonial, religious.). Postmodernists critique has encouraged many standpoint theorists to end the agenda of searching for a single women's standpoint that can claim feminist epistemic superiority. They opted to move to a pluralistic direction by welcoming multiple situated standpoints arising out of intersecting subordinated groups (Harding 1998; Collins 1990). Harding (1998) argued that a system of knowledge that integrates these multiple insights and evolves out from their unique experiences will be richer compared to one that draws on the insights of and develops from the predicaments of dominant groups alone. To make it simpler, in terms of knowing strategy, thinking from multiple standpoints from variety of subaltern perspectives gives more advantage than sticking in one's thinking to dominant perspective. This means, the standpoint theory moves the epistemic advantage point from the context of justification of being marginalized to the discovery of morally or politically significant truths arising out of multiple subaltern standpoints. This shift can also be understood in terms of pragmatic advantages: thinking from multiple and pluralistic standpoints allows the vision and realization of more just social relations (Collins 1990, Hartsock 1996).

Wylie (2003) explained among different versions of feminist standpoint two points are being shared. First, standpoint theory rejects essentialism or the idea that the certain groups reveals any standpoint would represent fixed nature of their group or that members of this group would do or to think the same. Second, standpoint theory rejects any intention to entitle automatic epistemic privilege to any particular standpoint. Wylie (2003) asserts that the social circumstance of "insider-outsiders" (or members of disadvantaged groups as subject of knowledge) can sometimes afford a contingent epistemic advantage in solving particular problems they encounter. Seen from this pluralistic orientation, feminist standpoints implies shared epistemic spirit with feminist postmodernism while at the same time their inclination also toward more empiricism 
pragmatic approach which is at many point shared with feminist empiricism.

Longino $(1990,2001)$ has developed more fully a conception of objectivity based on democratic discussion. Her key idea is that the production of knowledge is a social enterprise, secured through critical while cooperative interactions among inquirers. This strategy fully takes rational inquiry as social enterprises. As social enterprise, the results of this academic inquiry in considered to be more objective if they are more responsive to criticism. This notion developed from a long tradition including J.S. Mill, Karl Popper, and Paul Feyerabend (Lloyd 1997a). Feminists develop this tradition by proposing three aspects. First, by giving a more articulate conception of "all points of view," through emphasize on the influence of the social positions of inquirers on the representation models they create. Second, feminists suggest a more empirically component in the account of the social relational characteristic of different communities of inquiry (e.g., Potter 1993, 2001). Third, feminist theories give a greater stress on the importance of equality among imagined plural inquirers.

In Longino's (2001) proposal of epistemology, a rational inquiry is objective, and therefore its product can be accepted as knowledge, if it shows four requirements. First, it offers public rooms for the criticism of its knowledge claims. Second, it responds to criticisms by changing its contents of theories according to, and three, publicly considered standards of scientific evaluation. Last, it adheres to a norm of equality of epistemic authority among community of enquirers. The last component of objectivity, the requirement of acknowledgement of equality of intellectual authority represents the democratic feature of Longino's theory. However, it also invites criticism, given the demand to acknowledge equality among different enquirers with different expertise and competence. In respond these criticism, supporters of this democratic model of objectivity have specified the norm of equality in order to distinguish legitimate differences of expertise and competence among enquirers from illegitimate epistemic interaction. An illegitimate form of democratic model occurs when a group exercises its social power to exclude some criticisms such as those coming from disadvantaged groups from 
participating in the epistemic interaction (Anderson 1995b, Longino 2001).

During its development, theorists adopting postmodern feminists have shown similar direction toward other influential streams in feminist epistemology. Some feminists inspired by postmodernism sought middle and more stable bases that feminist empiricists and standpoint theorists can share. Donna Haraway (1989), considered as proponent of feminist postmodernist, showed exemplary attempt by expressing tributes to the achievements of feminist scholars adopting empiricist framework and standards. Haraway (1991) further have taken attempts to reconstruct models of objectivity and epistemic responsibility which show consistency with the principle of situated knowledge. Similarly, Fraser (1995) urged for reformulation of feminist postmodernism approach toward a more pragmatic orientation while employing fallibilism and contextualization of knowledge claims, avoiding categorical rejections of grand social theory, normative philosophy and even humanist values.

Today, the three feminist epistemological streams increasing show more agreement than disagreement and they share inclination toward each other. However, it is important to mention that different views regarding how social values give impact to objectivity do persist among the three streams (Intemann 2010). Feminist empiricist theory stressed how pluralism of values within enquirer community will allow critical examination of unquestioned underlying assumptions of rational inquiry. It also multiplies potential fruitful hypotheses. Meanwhile, feminist standpoint supporters argued that better values produce better theories. In response to this, feminist empiricists have accepted the value claim of standpoint theory with notes that these claims are kept contingent and local (Wylie and Nelson 2007).

\section{CONCLUSION}

In their early phase, feminist theories on epistemology and philosophy of science paid their greatest attention to explore general questions about the inter-link between gender and knowledge. They 
questioned: Do mainstream conceptions and practices of knowledge production, objectivity, and science embody masculine or androcentric feature and sentiment? Do men and women have different reasoning styles manifested in different ways of knowing? This new field of epistemic investigation has steadily evolved toward enquiries on different ways gender is constructed in practice of knowledge production in specific subject matters, among particular communities of inquiry, and using distinct methods. This shift to more local and particular investigation has led the three streams in feminist epistemological thinking into convergence direction.

As an epistemology tradition, feminist theories share commitment to reveal multiple-overlapping routes through which gender as social-cultural norms, ideology and political structure works in the production and reproduction of knowledge. The feminist theories maintain their focus on the principle of situated knowledge while giving strong emphasis on the interplay between facts and values. The tradition generally rejects the concept of transcendental-overreaching standpoints while encouraging plurality of theories. These themes are all in one way or the others shared by the three feminist epistemology streams.

Gender is not the only social-cultural dimension that shapes the production of knowledge. Epistemic authority is built upon a set symbols and values that includes not only gender, but also race, class, sexuality, culture, religion and age. If feminist epistemology is an embodiment liberating knowledge project, it must address all forms of domination because women in fact fill the population of every category of subordinated marginalised people. To claim for an epistemic liberatory project, feminists cannot only work for or about women, but all forms of subordinated groups.

\section{BIBLIOGRAPHY}

Addelson, Kathryn, 1983, "The Man of Professional Wisdom", In Harding and Hintikka, 165-86.

Alcoff, Linda and Elizabeth Potter Eds., 1993, Feminist Epistemologies, Routledge, New York and London. 
Anderson, Elizabeth. 1995a, "Feminist Epistemology: An Interpretation and a Defense", Hypatia, Vol. 10, No. 3, Analytic Feminism, pp. 50-84 1995b, "Knowledge, Human Interest and Objectivity in Feminist Epistemology", Philosophical Topics, 23: 27-58.

2004. "Uses of Value Judgments in Science: A General Argument, with Lessons from a Case Study of Feminist Research on Divorce", Hypatia, 19(1): 1-24.

Bordo, Susan, 1987, The Flight to Objectivity: Essays on Cartesiansm and Culture, State University of New York Press, New York.

Code, Lorraine, 1991, What Can She Know?, Ithaca, Cornell University Press, New York.

1993, “Taking Subjectivity into Account", in Alcoff, L. and E. Potter (Eds), Feminist Epistemologies, Routledge, New York and London.

Collins, Patricia Hill, 1990, Black feminist thought: Knowledge, consciousness, and the politics of empowerment, Unwin Hyman, Boston.

Daston, L., \& Peter Galison, P., (2007), Objectivity, Zone Books, New York.

Dotson, Kristie, 2011, Tracking Epistemic Violence, Tracking Practices of Silencing, Hypatia Issue 26 (2):236-257

Fraser, Nancy, 1995, "False Antithesis", In Benhabib, Butler, Cornell and Fraser.

Fraser, Nancy and Linda Nicholson. 1990. "Social Criticism without Philosophy", In Nicholson.

Fricker, Miranda 2007, Epistemic Injustice: Power and the Ethics of Knowing, Oxford Scholarship Online

Haraway, Donna, 1989, Primate Visions, Routledge, New York.

1991, "Situated Knowledges", In Simians, Cyborgs and Women, Routledge, New York.

Harding, Sandra, 1986, The science question in feminism, Cornell University Press, Ithaca.

1991, Whose science? Whose Knowledge?, Ithaca, Cornell University Press, N. Y.. 
1993, "Rethinking standpoint Epistemology: 'What is Strong Objectivity?'”, In Alcoff and Potter.

1998, Is Science Multicultural?: Postcolonialisms, Feminisms and Epistemologies, Bloomington, Indiana University Press, Ind..

Hartsock, Nancy, 1996, “Comment on Hekman's 'Truth and Method': Truth or Justice", Signs, 22: 367-73.

Hekman, Susan, 1996, Feminist Interpretations of Michel Foucault, The Pennysylvania State University Press.

Hookway, Christopher, 2010, Some Varieties of Epistemic Injustice: Reflections on Fricker, Episteme, Volume 7, Issue 2, pp. 151-163

Hrdy, Sarah, 1986, Empathy, polyandry, and the myth of the coy female, In Feminist approaches to science, ed. Ruth Bleier, Pergamon, New York.

Intemann, Kristen, 2011, Diversity and Dissent in Science: Does Democracy Always Serve Feminist Aims?, In Heidi E. Grasswick Feminist Epistemology and Philosophy of Science: Power in Knowledge (pp.111132), Springer.

Jaggar, Allison, 1989, "Love and Knowledge: Emotion in feminist Epistemology", In Garry and Pearsall.

Keller, Evelyn Fox, 1983, A feeling for the organism, Freeman, New York. 1985, The force of the pacemaker concept in theories of aggregation in cellular slime mold, In Reflections on gender and science, Yale University Press, New Haven.

Little, Margaret, 1995, "Seeing and Caring: the Role of Affect in Feminist Moral epistemology", Hypatia, 10: 117-137.

Lloyd, Genevieve, 1984, The Man of Reason: 'Male' and 'Female' in Western Philosophy, Mathuen and Co ltd, London.

Lloyd, Elisabeth, 1997a. "Feyerabend, Mill and Pluralism", Philosophy of Science, 64: 396-407.

Longino, Helen, 1990, Science as social knowledge, Princeton University Press, Princeton, NJ. 
1993a, Essential tensions -- Phase two: Feminist, philosophical, and social studies of science, In A mind of one's own, See Antony and Witt 1993.

1993b, Subjects, power, and knowledge: Description and prescription in feminist philosophies of science, In Feminist epistemologies, See Alcoff and Potter 1993.

1994, "In Search of Feminist Epistemology", Monist, 77: 472-485.

2001, The Fate of Knowledge, Princenton University Press, Princenton.

Margonis, Frank, 2007, John Dewey, W. E. B. Du Bois, and Alain Locke: A Case Study in White Ignorance and Intellectual Segregation. in Shannon Sullivan and Nancy Tuana, Race and Epistemologies of Ignorance. State University of New York Press

Nelson, Lynn, 1993, Epistemological communities, In Feminist epistemologies, See Alcoff and Potter 1993.

1995. "The Very Idea of Feminist Epistemology", Hypatia, Vol. 10, No. 3, pp. 31-49

Potter, Elizabeth, 1993, Gender and epistemic negotiation, In Feminist epistemologies, See Alcoff and Potter 1993.

2001, Gender and Byle's Law of Gases, Indiana University Press, Bloomington.

Shapin, Steven, 1994, A Social History of Truth, Civility and science in Seventeeth-century England, Chicago University Press, Chicago.

Solomon, Miriam, 2001, Social Empiricism, MIT Press, London.

Sullivan, Shannon and Nancy Tuana, Race and Epistemologies of Ignorance.

State University of New York Press Tuana, Nancy, ed., 1989, Feminism and science, Indiana University Press, Bloomington.

Wylie, Alison, 2004, "Why Standpoint Matters" in Sandra Harding, The Feminist Standpoint Theory Reader, Routledge, New York and London.

Wylie, Alison and Hankinson Nelson, 2007, "Coming to terms with the values of science: Insights from feminist science studies scholarship", in Harold Kincaid, John Dupré, and Alison Wylie, Value-free science: Ideals and illusions, Oxford University Press, Oxford. 